\title{
Opodatkowanie podatkiem od czynności cywilnoprawnych przekształcenia spółki osobowej w inną spółkę osobową - analiza na tle orzecznictwa sądów administracyjnych
}

\section{Taxation with a tax on civil law transactions}

of a transformation of a general partnership into another partnership - an analysis against the background of administrative courts' rulings

Streszczenie. Zgodnie z ustawą o podatku od czynności cywilnoprawnych warunkiem opodatkowania przekształcenia spółki osobowej w inną spółkę osobową jest zwiększenie majątku spółki powstałej w wyniku przekształcenia. To oznacza, że jeśli w ramach przekształcenia nie ma miejsca wniesienie (podwyższenie) wkładów, wówczas majątek spółki nie ulega zwiększeniu. W związku z tym w takiej sytuacji przekształcenie nie podlega opodatkowaniu podatkiem od czynności cywilnoprawnych. Tym samym nie jest trafny dominujący w orzecznictwie 
pogląd, zgodnie z którym opodatkowaniu podlega różnica między wartością majątku spółki przekształcanej a wartością opodatkowanych uprzednio wkładów.

Słowa kluczowe: podatek od czynności cywilnoprawnych; przekształcenie; wartość wkładów; wartość majątku.

\begin{abstract}
Pursuant to the Polish Act on tax on civil law transactions, transformation of a general partnership into another type of a partnership may be taxed if it causes an increase of the partnership's assets value (which is established as a result of the transformation). This means that the partnership's assets value remains unchanged, if, as part of the transformation, there is no increase of partners' contributions. In such a situation, transformation is not taxable with tax on civil transactions. The dominating in judicature standpoint according to which the tax base is the difference between the value of the transforming partnership's assets and the value of previously taxed contributions, is - therefore - incorrect.
\end{abstract}

Keywords: tax on civil law transactions; a transformation; contributions' value; an assets' value.

\title{
1. Wprowadzenie
}

Powodem dla poddania analizie wskazanego w tytule zagadnienia dogmatycznoprawnego są prezentowane w orzecznictwie sądów administracyjnych tezy dotyczące opodatkowania podatkiem od czynności cywilnoprawnych (dalej: PCC) przekształcenia spółki osobowej w inną spółkę osobową ${ }^{1}$. Zgodnie z dominującą w judykaturze interpretacją przepisów ustawy z dnia 9 września 2000 r. o podatku od czynności cywilnoprawnych $^{2}$ opodatkowaniu PCC podlega różnica między wartością majątku

\footnotetext{
1 Na gruncie przepisów o podatku od czynności cywilnoprawnych przez spółkę osobową należy rozumieć spółkę cywilną, jawną, partnerską i komandytową. Jednocześnie, choć z regulacji tych wynika, że spółką osobową jest także spółka komandytowoakcyjna, to jednak zgodnie z wyrokiem TSUE z 22 kwietnia 2015 r. C-357/13 (Drukarnia Multipress sp. z o.o. przeciwko Ministrowi Finansów) powinna być ona traktowana jak spółka kapitałowa.

2 Ustawa z dnia 9 września 2000 r. o podatku od czynności cywilnoprawnych (tekst jedn. Dz.U. z 2020 poz. 815).
} 
spółki przekształcanej a wartością opodatkowanych uprzednio wkładów ${ }^{3}$. Rezultatem takiego sposobu wykładni u.p.c.c. jest opodatkowanie PCC także w przypadku, gdy w ramach przekształcenia nie ma miejsca wniesienie (podwyższenie) wkładów i w konsekwencji nie występuje jakakolwiek różnica miedzy wartością majątku spółki przekształcanej i przekształconej.

Zapatrywania prawne judykatury wydają się pozostawać w sprzeczności z art. 1 ust. 1 pkt 2 oraz art. 1 ust. 3 pkt 3 u.p.c.c., z których wynika, że przekształcenie podlega opodatkowaniu PCC, jeśli prowadzi do zwiększenia podstawy opodatkowania (tj. wartości wkładów) oraz majątku spółki. Prezentowane w judykaturze koncepcje trudno także pogodzić z brzmieniem art. 6 ust. 1 pkt 8 lit. f) u.p.c.c., który stanowi, że podstawą opodatkowania jest wartość wkładów do spółki powstałej w wyniku przekształcenia. Powyższe spostrzeżenia wyznaczają problem badawczy niniejszego artykułu. Jest nim mianowicie ustalenie, czy opodatkowanie PCC powinno mieć miejsce także przypadku, gdy w ramach przekształcenia nie dochodzi do wniesienia (podwyższenia) wkładów.

\section{Stanowisko sądów - argumenty}

W pierwszej kolejności należy zauważyć, że podstawą dominującego w orzecznictwie ${ }^{4}$ poglądu jest założenie, że pod pojęciem wkładu do spółki osobowej powstałej w wyniku przekształcenia należy rozumieć nie tyle wkłady wnoszone (podwyższane) przez wspólników, ale w istocie majątek spółki przekształcanej, który - w efekcie przekształcenia - staje się majątkiem spółki przekształconej. Sądy wskazują w tym zakresie,

3 Zob. orzeczenia przywoływane w przypisach 5-7. Brak powtórnego opodatkowania wkładów opodatkowanych PCC sądy wywodzą z brzmienia art. 9 ust. 1 pkt 11 lit. a) u.p.c.c., z którego wynika, że zwolnione z PCC są umowy spółki i ich zmiany związane z przekształceniem lub łączeniem spółek w części wkładów do spółki albo kapitału zakładowego, których wartość była uprzednio opodatkowana PCC lub podatkiem od wkładów kapitałowych do spółek kapitałowych na terytorium państwa członkowskiego innego niż Polska albo od których zgodnie z prawem państwa członkowskiego podatek nie był naliczany.

4 W ramach opracowania zostały przeanalizowane wyroki sądów administracyjnych z lat 2014-2020 - są one przywoływane w kolejnych przypisach. 
że: „(...) opodatkowaniu podlega wartość wkładów z samego przekształcenia, bez żadnych dodatkowych wkładów wnoszonych przy okazji przekształcenia (...)" ${ }^{\text {5 }}$ W ocenie judykatury za takim wnioskiem przemawia m.in. porównanie treści art. 6 ust. 1 pkt 8 lit. b) oraz lit. f) u.p.c.c. Zgodnie z pierwszym z przepisów podstawę opodatkowaniu przy wniesieniu (podwyższeniu) wkładów do spółki osobowej stanowi wartość wkładów powiększających majątek spółki osobowej. W związku z tym w ocenie sądów administracyjnych przez wartość wkładów, o której mowa w art. 6 ust. 1 pkt 8 lit. f) u.p.c.c., nie można rozumieć wkładów wniesionych (podwyższonych) w ramach przekształcenia, gdyż te podlegałyby opodatkowaniu na podstawie art. 6 ust. 1 pkt 8 lit. b). Jak argumentują sądy administracyjne, art. 6 ust. 1 pkt 8 lit. f) u.p.c.c. byłby wówczas pozbawiony treści normatywnej i w konsekwencji byłby zbędny. Taki sposób wykładni - zdaniem sądów - pozostawałby w sprzeczności z zasadą zakazu wykładni per non est, w świetle której nie jest dopuszczalna taka interpretacja przepisów prawa, która czyni określone fragmenty tekstu ustawy zbędnymi ${ }^{6}$.

Po drugie, w świetle zapatrywań judykatury uzyskanie przez spółkę powstałą w wyniku przekształcenia - oprócz majątku w postaci wkładów wniesionych do spółki przed przekształceniem - także innych składników majątkowych oznacza, że dochodzi do zwiększenia majątku spółki. Tym samym zgodnie z dominującą linią orzeczniczą spełniona jest wówczas przesłanka opisana w art. 1 ust. 3 pkt 3 u.p.c.c. W prezentowanej argumentacji sądy odwołują się także do racji celowościowych i systemowych. Zdaniem judykatury brak opodatkowania nadwyżki (ponad wkłady opodatkowane uprzednio w spółce przekształcanej) doprowadziłby: „(...) do wyłomu w systemie opodatkowania podatkiem od czynności cywilnoprawnych majątku spółki. Powstałaby bowiem sytuacja zasilenia w formie

5 Zob. wyroki NSA z 4 lutego 2020 r., II FSK 498/18, WSA w Poznaniu z 31 października 2017 r., I SA/Po 486/17 oraz WSA w Krakowie z 19 stycznia 2018 r., I SA/Kr 1270/17. Zarówno te, jak i wszystkie inne przywoływane dalej wyroki sądów administracyjnych pochodzą z Centralnej Bazy Orzeczeń Sądów Administracyjnych (CBOSA).

6 Zob. wyroki NSA z 4 lutego 2020 r., II FSK 498/18, WSA w Poznaniu z 31 października 2017 r., I SA/Po 486/17 oraz WSA w Warszawie z 24 lipca 2014 r. III SA/Wa 161/14. 
wkładów spółki osobowej, które nie podlegałyby opodatkowaniu podatkiem od majątku"7.

Należy jednak wskazać, że wskazana powyżej argumentacja nie jest podzielana przez wszystkie sądy administracyjne. Odmienny pogląd w kwestii opodatkowania PCC przekształcenia spółki osobowej w inną spółkę osobową wyraził WSA w Bydgoszczy w wyroku z 14 lipca 2020 r., I SA/Bd 250/20. Sąd wskazał m.in., że podstawą opodatkowania PCC jest wówczas wartość wkładów wnoszonych (podwyższanych) w ramach przekształcenia. Przy czym przez wkłady należy rozumieć wkłady wnoszone (podwyższane) przez wspólników, nie zaś wartość majątku spółki przekształcanej, który stanie się majątkiem spółki przekształconej. Należy wskazać, że pogląd wyrażony przez WSA w Bydgoszczy jest aprobowany przez część doktryny prawa podatkowego ${ }^{8}$.

\section{Wkłady do spółki powstałej w wyniku przekształcenia}

Polemikę z poglądami judykatury należy rozpocząć od stwierdzenia, że u podstaw dominującej obecnie linii orzeczniczej leży błędne rozumie-

7 Zob. wyroki: NSA z 4 lutego 2020 r., II FSK 498/18, WSA w Poznaniu z 31 października 2017 r., I SA/Po 486/17 oraz WSA w Krakowie z 19 stycznia 2018 r., I SA/Kr 1270/17.

8 Poglądy zbieżne z wyrażonym przez WSA w Bydgoszczy przedstawili m.in. A. Żądło, Przekształcenie spótki osobowej w innq spółkę osobowq [w:] A. Mariański (red.), Opodatkowanie spółek osobowych i ich wspólników, Warszawa 2018, LEX/el. oraz P. Karwat, Przekształcenie spółki jawnej, komandytowej, partnerskiej i cywilnej w innq tego samego typu osobowq spółkę handlowq [w:] H. Litwińczuk (red.), Opodatkowanie spółek, Warszawa 2016, LEX/el. Z kolei, jak się wydaje, odmienne zapatrywanie zaprezentowała H. Filipczyk, która stwierdziła, że: „(...) celem ustalenia podstawy opodatkowania przy przekształceniu spółek nie należy badać, czy majątek spółki (substrat majątkowy) uległ zwiększeniu, ale przyjąć jako tę podstawę majątek dotychczas nieopodatkowany. Oznacza to de facto zbadanie w punkcie wyjścia, jaka wartość podlegałaby opodatkowaniu z tytułu utworzenia spółki powstałej z przekształcenia, a następnie odjęcie od niej wartości już opodatkowanej w spółce przekształconej (oraz wartości, od której zgodnie z prawem państwa członkowskiego podatek nie był naliczany w spółce przekształcanej, por. art. 9 pkt 11 lit. a u.p.c.c.). Jest to metodologia poprawna”, zob. H. Filipczyk, Komentarz do art. 6 u.p.c.c. [w:] H. Filipczyk, Podatek od czynności cywilnoprawnych. Komentarz, Warszawa 2015, LEX/el. 
nie pojęcia wkładu do spółki. Pod tym pojęciem sądy administracyjne rozumieją bowiem majątek spółki przekształcanej, który wskutek przekształcenia stanie się majątkiem spółki przekształconej. Nie jest to pogląd trafny z tego względu, że wspólnicy nie wnoszą do spółki przekształconej majątku spółki przekształcanej.

W tym kontekście należy zauważyć, że jak wynika z art. 28 ustawy z dnia 15 września 2000 r. - Kodeks spółek handlowych ${ }^{9}$, majątek spółki stanowi wszelkie mienie ${ }^{10}$ wniesione jako wkład lub nabyte przez spółkę w czasie jej istnienia. To oznacza, że majątek spółki konstytuują wkłady wniesione przez wspólników, określane również jako pierwotny majątek spółki $^{11}$, oraz mienie nabyte w czasie jej funkcjonowania. Dodatkowo należy zaakcentować, że majątek spółki osobowej nie należy do wspólników, ale do samej spółki ${ }^{12}$. To oznacza, że wspólnicy nie są dysponentami majątku spółki przekształcanej, w tym nie wnoszą go w postaci wkładu do spółki przekształconej.

Dodatkowo należy zauważyć, że zgodnie z art. 553 § 1 Kodeksu spółek handlowych spółce przekształconej przysługują wszystkie prawa i obowiązki spółki przekształcanej. Powyższy przepis statuuje zasadę kontynuacji praw i obowiązków spółki przekształcanej. Jak wskazuje się w judykaturze, nie ma wówczas „(...) poprzednika i następcy prawnego, istnieje natomiast ta sama spółka w zmienionej formie prawnej na inny

9 Ustawa z dnia 15 września 2000 r. - Kodeks spółek handlowych (tekst jedn. Dz.U. z 2020 poz. 1526 ze zm.), dalej: Kodeks spółek handlowych.

10 Mieniem jest własność i inne prawa majątkowe. Jak wskazuje się w doktrynie, na mienie składają się jedynie aktywa, nie zaś obowiązki danego podmiotu. Zob. Z. Radwański, Prawo cywilne - część ogólna, Warszawa 2005, s. 141.

11 B. Borowy, Komentarz do art. 28 Kodeksu spółek handlowych [w:] Z. Jara (red.), Kodeks spólek handlowych. Komentarz. Wyd. 3, Warszawa 2020, Legalis/el.

12 Zob. K. Kułak, Wycofanie składnika majq̨tku spółki jawnej z działalności gospodarczej i nieodpłatne przekazanie go na użytek osobisty wspólników w świetle regulacji kodeksu spółek handlowych [w:] M. Dumkiewicz, K. Kopaczyńska-Pieczniak, J. Szczotka (red.), Sto lat polskiego prawa handlowego. Księga jubileuszowa dedykowana Profesorowi Andrzejowi Kidybie. Tom I, Warszawa 2020, LEX/el. Reguła ta nie dotyczy jednak spółki cywilnej. Zgodnie z przepisami prawa cywilnego majątek spółki cywilnej stanowi współwłasność wspólników. Zob. A. Kidyba, K. Kopaczyńska-Pieczniak, Komentarz do art. 863 Kodeksu cywilnego [w:] A. Kidyba (red.), Kodeks cywilny. Komentarz. Tom III. Zobowiq̨zania - część szczególna, Warszawa 2014, LEX/el. 
ustawowy typ spółki”13. To oznacza, że majątek spółki przekształcanej nie jest wnoszony przez wspólników do spółki przekształconej jako wkład, ale przysługuje spółce przekształconej z mocy prawa. Trafnie na powyższe kwestie zwrócił uwagę WSA w Bydgoszczy ${ }^{14}$, który wskazał m.in., że: „(...) wkładem jest to, co wspólnik wnosi do spółki - a nie to, co wypracowała sama spółka (choćby i taka spółka, która następnie uległa przekształceniu). (...) Majątek wypracowany przez spółkę jawną nie «przedostaje się» do spółki komandytowej w postaci wkładów”.

W związku z powyższym należy stwierdzić, że w razie braku wniesienia (podwyższenia) wkładów przez wspólników nie jest spełniona jedna z przesłanek opodatkowania przekształcenia PCC, tj. zwiększenie podstawy opodatkowania w postaci wniesienia (podwyższenia) wkładów. W takiej sytuacji, ze względu na brak wkładów wnoszonych w ramach przekształcenia, nie wystąpi podstawa opodatkowania, która ze względu na brak wkładów będących podstawą opodatkowania wyniesie 0 zł.

\section{Zwiększenie majątku spółki osobowej}

W sytuacji, gdy w ramach przekształcenia nie ma miejsca wniesienie (podwyższenie) wkładów, nie dochodzi również do zwiększenia majątku spółki przekształconej. Należy bowiem zauważyć, że wspólnicy mogą zaliczyć na poczet wkładów w spółce przekształconej wartość wkładów wniesionych przez nich do spółki przekształcanej. To oznacza, że przekształcenie (zmiana formy prawnej) nie musi wiązać się z wniesieniem (podwyższeniem) wkładów - wspólnicy mogą bowiem poprzestać na zachowaniu dotychczasowej struktury wkładów ${ }^{15}$. W tym kontekście na-

13 Postanowienie SN z 30 czerwca 2020 r., I CZ 15/20, LEX nr 3046030.

14 Wyrok WSA w Bydgoszczy z 14 lipca 2020 r., I SA/Bd 250/20. Tożsamy pogląd wyrazili także A. Żądło, Przekształcenie spółki osobowej... oraz P. Karwat, Przekształcenie spółki jawnej...

15 Nie ma oczywiście przeszkód, aby w ramach przekształcenia dotychczasowi wspólnicy wnieśli do spółki dodatkowe wkłady. Wniesienie wkładów może również wynikać z przystąpienia do spółki nowego wspólnika. Na dopuszczalność poszerzenia grona wspólników w ramach przekształcenia wskazuje M. Rodzynkiewicz, Komentarz do 
leży przypomnieć, że spółka przekształcona jest kontynuatorem działalności prowadzonej przez spółkę przekształcaną. W związku z tym przysługują jej te same prawa i obowiązki, które przysługiwały spółce przekształcanej. Konsekwencją powyższych spostrzeżeń jest wniosek, że w razie braku wniesienia (podwyższenia) wkładów majątek spółki przekształconej będzie taki sam, jak majątek spółki przekształcanej ${ }^{16}$. Tym samym, wbrew poglądom przedstawianym w orzecznictwie, w razie braku wniesienia (podwyższenia) wkładów nie dojdzie do przyrostu majątku, który mógłby zostać opodatkowany PCC ${ }^{17}$.

\section{Naruszenie zasady zakazu wykładni per non est?}

W orzecznictwie sądów administracyjnych wskazuje się, że za opodatkowaniem przekształcenia PCC w sytuacji, gdy wspólnicy nie wnoszą (podwyższają) wkładów, przemawia jedna z zasad wykładni prawa, a mianowicie zakaz wykładni per non est. W myśl tej zasady nie można dokonywać interpretacji przepisów prawa w taki sposób, aby pewne jego fragmenty okazały się zbędne ${ }^{18}$. Zdaniem judykatury argumentem za rozumieniem pojęcia wkładów na gruncie art. 6 ust. 1 pkt 8 lit. f) u.p.c.c. jako wartości całego majątku spółki przekształcanej jest m.in. fakt, że gdyby chodziło w nim jedynie o wartość wkładów wniesionych (podwyższonych) przez wspólników, wówczas podstawa opodatkowania zostałaby określona w oparciu o art. 6 ust. 1 pkt 8 lit. b) u.p.c.c. W takiej sytuacji art. 6 ust. 1 pkt 8 lit. f) u.p.c.c. byłby regulacją, która nie posiada treści normatywnej.

art. 553 Kodeksu spółek handlowych [w:] M. Rodzynkiewicz, Kodeks spółek handlowych. Komentarz, Warszawa 2018, LEX/el. Odmiennie: M. Tofel, Komentarz do art. 553 Kodeksu spółek handlowych [w:] J. Bieniak, M. Bieniak, G. Nita-Jagielski, K. Oplustil, R. Pabis, A. Rachwał, M. Spyra, G. Suliński, M. Tofel, M. Wawer, R. Zawłocki, Kodeks spółek handlowych. Komentarz, Warszawa 2019, Legalis/el.

16 Tak też A. Żądło, Przekształcenie spółki osobowej...

17 Na kwestie zasygnalizowane w powyższym akapicie wskazywał WSA w Bydgoszczy w wyroku z 14 lipca 2020 r., I SA/Bd 250/20.

18 L. Morawski, Wstęp do prawoznawstwa, Toruń 2009, s. 146; L. Morawski, Zasady wykładni prawa, Toruń 2010, s. 122. 
W tym kontekście należy odwołać się do opisywanego w nauce prawa pojęcia superfluum, które może być definiowane jako powtórzenie przepisu (normy) prawnej w innej części aktu prawnego ${ }^{19}$. Występowanie w przepisach prawa superfluum może wynikać m.in. z zamiaru doprecyzowania (klaryfikacji) przez ustawodawcę skutków prawnych określonego stanu faktycznego ${ }^{20}$. W związku z tym superfluum bywa również określane jako tzw. wzmocnienie ustawowe polegające na zaakcentowaniu określonego stanu rzeczy ${ }^{21}$. Superfluum może służyć wówczas podkreśleniu w danym przepisie tego „,...) co i tak wynika z innych norm, aby wykluczyć jakiekolwiek wątpliwości interpretacyjne”22. Należy wskazać, że powtórzenie ustawowe nie musi być oceniane ujemnie. Można bowiem spotkać liczne wypowiedzi przedstawicieli doktryny prawa, w których superfluum jest określane jako zjawisko nieszkodliwe ${ }^{23}$.

Przenosząc powyższe spostrzeżenia na grunt u.p.c.c., należy stwierdzić, że art. 6 ust. 1 pkt 8 lit. f) pełni rolę wzmocnienia ustawowego (superfluum), którego celem jest uniknięcie wątpliwości, co stanowi podstawę opodatkowania przy przekształceniu spółki. Należy bowiem zauważyć, że wniesieniu (podwyższeniu) wkładów do istniejącej spółki towarzyszą odmienne okoliczności faktyczne i prawne niż w przypadku wniesienia (podwyższenia) wkładów w ramach przekształcenia. W pierwszym przypadku wkłady są wnoszone do podmiotu, którego forma prawna nie ulega zmianie. W drugim zaś dochodzi do zmiany formy prawnej spółki,

19 M. Kłodawski, Trzy ujęcia nadmiarowości w polskim prawie stanowionym [w:] Z. Dziemianko, W. Stach (red.), Rzeczywistość społeczna w badaniach młodych naukowców, Poznań 2012, s. 158.

20 Co koresponduje z rzymską maksymą superflua admittere securius est, quam necessaria omittere (bezpieczniej jest dopuścić rzeczy zbyteczne aniżeli opuścić rzeczy konieczne). Zob. D. Drajewicz, Zabezpieczenie majq̨tkowe w znowelizowanym Kodeksie postępowania karnego, „Palestra” 2017, nr 1-2, s. 87. Uchwała SN z dnia 7 września 1995 r. I PZP 23/95, LEX nr 14726.

D. Drajewicz, Zabezpieczenie majątkowe..., s. 87.

23 Zob. przykładowo P. Konieczniak, Uwagi o pojmowaniu typów zmodyfikowanych [w:] J. Brzezińska, J. Giezek (red.), Zmodyfikowane typy przestępstw w teorii i praktyce sqqdowej, Warszawa 2017, LEX/el.; M. Michalski, Komentarz do art. 200 Kodeksu spółek handlowych [w:] A. Kidyba (red.), Kodeks spółek handlowych. Tom II. Komentarz do art. 151-300, Warszawa 2018, LEX/el.; J. Jagielski, Obywatelstwo polskie. Komentarz do ustawy, Warszawa 2016, LEX/el., komentarz do art. 31. 
zaś same wkłady z reguły będą wnoszone (podwyższane) w spółce przekształconej $^{24}$. Dodatkowo, samemu przekształceniu towarzyszą okoliczności niewystępujące w przypadku standardowego wniesienia (podwyższenia) wkładów, takie jak sporządzenie planu przekształcenia oraz podjęcie uchwały w przedmiocie przekształcenia. Powyższe oznacza, że art. 6 ust. 1 pkt 8 lit. f) nie jest zbędny. Jego celem jest bowiem doprecyzowanie, co stanowi podstawę opodatkowania w przypadku przekształcenia. W związku z tym odwoływanie się do zasady zakazu wykładni per non est nie jest w tym przypadku trafne.

\section{Zakaz wykładni homonimicznej}

Dominujący w orzecznictwie sposób interpretacji u.p.c.c. stoi jednocześnie w sprzeczności z inną zasadą wykładni prawa, a mianowicie zakazem wykładni homonimicznej. W jej świetle występującym w obrębie ustawy tym samym zwrotom nie można nadawać różnych znaczeń ${ }^{25}$. Tymczasem u podstaw dominującej obecnie linii orzeczniczej leży m.in. założenie, że pod pojęciem wkładów, o których stanowi art. 6 ust. 1 pkt 8 lit. f) u.p.c.c., należy rozumieć nie wkłady wnoszone (podwyższane) przez wspólników, ale majątek spółki przekształcanej, który po przekształceniu stanie się majątkiem spółki przekształconej. Reprezentatywne dla wskazanej wyżej linii orzeczniczej jest stanowisko, zgodnie z którym: „(...) skoro wartość wkładów przy przekształceniu stanowi podstawę opodatkowania, oznacza to, że opodatkowaniu podlega wartość wkładów z samego przekształcenia, bez żadnych dodatkowych wkładów wnoszonych przy okazji przekształcenia, gdyż wniesienie dodatkowych wkładów podlegałoby opodatkowaniu na podstawie art. 6 ust. 1 pkt 8 lit. b u.p.c.c.”26. Należy zauważyć, że taki sposób wykładni prowadzi do nadawania pojęciu

24 O braku zbędności art. 6 ust. 1 pkt 8 lit. f) u.p.c.c. - choć bez odwoływania się do koncepcji superfluum - piszą także P. Karwat, Przekształcenie spółki jawnej... oraz A. Żądło, Przekształcenie spółki osobowej...

25 L. Morawski, Wstęp do prawoznawstwa..., s. 146; L. Morawski, Zasady wykładni prawa..., s. 120.

26 Wyrok WSA w Poznaniu z 31 października 2017 r., I SA/Po 486/17. 
„wkładów do spółki” odmiennego znaczenia w różnych jednostkach redakcyjnych u.p.c.c.

Jak wynika bowiem z art. 6 ust. 1 pkt 8 lit. a) u.p.c.c., przy zawarciu umowy spółki osobowej podstawą opodatkowania jest wartość wkładów do spółki osobowej. Z kolei, jak stanowi art. 6 ust. 1 pkt 8 lit. b) u.p.c.c., przy wniesieniu lub podwyższeniu wkładów do spółki osobowej podstawą opodatkowania jest wartość wkładów powiększających majątek spółki. W powyższych przypadkach nie budzi wątpliwości, że podstawą opodatkowania są wkłady do spółki wnoszone (podwyższane) przez wspólników. Jednocześnie, zgodnie art. 6 ust. 1 pkt 8 lit. f) u.p.c.c., w przypadku przekształcenia podstawą opodatkowania również jest wartość wkładów do spółki. Mimo że wskazane powyżej przepisy zawierają to samo sformułowanie (wartość wkładów), to zgodnie z interpretacją aprobowaną w judykaturze pojęcie wkładów na gruncie art. 6 ust. 1 pkt 8 lit. f) u.p.c.c. powinno być interpretowane nie jako wartość wkładów wnoszonych do spółki przez wspólników, ale jako wartość majątku spółki przekształcanej. W konsekwencji temu samemu zwrotowi nadawane jest odmienne znaczenie na gruncie poszczególnych jednostek redakcyjnych u.p.c.c., co pozostaje w sprzeczności z zasadą zakazu wykładni homonimicznej.

\section{Dopuszczalność odejścia od rezultatów wykładni językowej}

W judykaturze wskazuje się, że za opodatkowaniem PCC przekształcenia spółki osobowej w inną spółkę osobową w przypadku, gdy nie dochodzi do wniesienia (podwyższenia) wkładów przez wspólników, przemawiają także racje celowościowe i systemowe. W orzecznictwie twierdzi się m.in., że „(...) nie można poprzestać na literalnej wykładni art. 1 ust. 3 pkt 3 u.p.c.c. Aby odkodować treść normy prawnej zawartej w tym przepisie, należy dokonać wykładni systemowej wewnętrznej i celowościowej regulacji zawartych w ustawie odnoszących się do sposobu opodatkowania spółek»"27. Sądy administracyjne wskazują również, że przeciwne ro-

27 Wyrok WSA w Warszawie z 24 lipca 2014 r., III SA/Wa 161/14. 
zumowanie „(...) doprowadziłoby do wyłomu w systemie opodatkowania podatkiem od czynności cywilnoprawnych majątku spółki. Powstałaby bowiem sytuacja zasilenia w formie wkładów spółki osobowej, które nie podlegałyby opodatkowaniu podatkiem od majątku” ${ }^{\text {"2 }}$. Powyższa argumentacja determinuje kilka spostrzeżeń.

Po pierwsze, jak wynika z przytoczonych zapatrywań sądów administracyjnych, przyjęcie poglądu o opodatkowaniu przekształcenia także w sytuacji, gdy nie ma miejsca wniesienie (podwyższenie) wkładów, wymaga odstąpienia od rezultatów wykładni językowej i posiłkowania się uzasadnieniem natury celowościowej i systemowej. To z kolei oznacza, że sądy dostrzegają, że rezultatem wykładni językowej jest brak opodatkowania przekształcenia, jeśli w jego ramach nie dochodzi do wniesienia (podwyższenia) wkładów. Gdyby było inaczej, to sądy nie musiałyby odwoływać się do wykładni celowościowej i systemowej, ponieważ dominujący $\mathrm{w}$ orzecznictwie pogląd miałby uzasadnienie $\mathrm{w}$ językowym brzmieniu u.p.c.c. Tak jednak nie jest $\mathrm{i}$ - jak wynika $\mathrm{z}$ analizy uzasadnień wyroków sądów administracyjnych - judykatura dostrzega, że językowa wykładnia u.p.c.c. prowadzi do wniosku, że brak wniesienia (podwyższenia) wkładów przez wspólników oznacza brak opodatkowania przekształcenia PCC.

Po drugie, skoro sądy administracyjne odstępują od językowego brzmienia u.p.c.c., należy ustalić, czy w analizowanych przez sądy przypadkach pominięcie rezultatów interpretacji językowej jest dopuszczalne.

Po trzecie, nawet jeśli odstąpienie od rezultatów wykładni językowej na rzecz wyników wykładni celowościowej i systemowej byłoby dopuszczalne, to dla kompletności analizy należy zidentyfikować, jakie konkretnie argumenty natury celowościowej i systemowej miałyby przemawiać za opodatkowaniem PCC przekształcenia, w ramach którego nie dochodzi do wniesienia (podwyższenia) wkładów.

Rozważania w tym zakresie należy rozpocząć od stwierdzenia, że wykładnia językowa jest uznawana za podstawową metodę interpretacji aktu prawnego. Wynika to m.in. z tego, że jak wskazuje się w literatu-

28 Wyroki: NSA z 4 lutego 2020 r., II FSK 498/18, WSA w Poznaniu z 31 października 2017 r., I SA/Po 486/17 oraz WSA w Krakowie z 19 stycznia 2018 r., I SA/Kr 1270/17. 
rze, obywatel powinien móc „(...) polegać na tym, co ustawodawca w tekście prawnym powiedział, a nie na tym, co zamierzał powiedzieć (...)”29. Możność ustalenia treści ciążących na jednostce praw i obowiązków jest istotna zwłaszcza w prawie podatkowym, którego istota sprowadza się do transferu środków pieniężnych od podatnika do państwa lub jednostki samorządu terytorialnego ${ }^{30}$.

Skoro więc wykładnia językowa stanowi podstawowy sposób dekodowania treści norm podatkowoprawnych, to należy odpowiedzieć na pytanie, w jakich sytuacjach dopuszczalne jest pominięcie jej rezultatów. Doktryna prawa wskazuje na kilka tego typu przypadków. Po pierwsze, wykorzystanie innych metod wykładni może mieć miejsce wtedy, gdy rezultaty wykładni językowej nie są jednoznaczne. Po drugie, odejście od wykładni językowej jest dopuszczalne, jeśli jej wyniki są jednoznaczne, ale stoją $\mathrm{w}$ sprzeczności $\mathrm{z}$ podstawowymi wartościami systemu prawa (w tym wartościami chronionymi konstytucyjnie). Po trzecie, pominięcie rezultatów wykładni językowej jest możliwe również w przypadku, gdy wykładnia językowa prowadzi do absurdalnych lub nieracjonalnych wniosków. Po czwarte, argumentem za odejściem od wyników wykładni językowej może być również identyfikacja luki w prawie ${ }^{31}$. Należy jednak wskazać, że mimo wystąpienia wskazanych wyżej przypadków odstąpienie od wyników wykładni gramatycznej nie powinno mieć jednak miejsca, jeśli skutkowałoby to pogorszeniem sytuacji obywateli ${ }^{32}$.

29 L. Morawski, Wstęp..., s. 144.

30 M. Kalinowski, Podmiotowość podatkowoprawna [w:] B. Brzeziński (red.), Prawo podatkowe. Teoria. Instytucje. Funkcjonowanie, Toruń 2009, s. 62.

31 Przywoływane w niniejszym akapicie cztery przypadki, w których można odstąpić od rezultatów wykładni językowej, zostały opisane w: B. Brzeziński, Wstęp do nauki prawa podatkowego, Toruń 2003, s. 197 oraz B. Brzeziński, Wykładnia prawa podatkowego [w:] B. Brzeziński (red.), Prawo podatkowe. Teoria. Instytucje. Funkcjonowanie, Toruń 2009, s. 426.

32 M. Zieliński, Wyznaczniki reguł wykładni prawa, „Ruch Prawniczy, Ekonomiczny i Socjologiczny” 1998, nr 3 i 4, s. 17-18. Przenosząc sformułowany przez M. Zielińskiego pogląd na grunt prawa podatkowego, B. Brzeziński stwierdził, że zastosowanie - innych niż językowa - metod wykładni nie może pogarszać sytuacji podatnika. Zob. B. Brzeziński, Wstęp do nauki..., s. 195-198; B. Brzeziński, Wykładnia prawa podatkowego..., s. 427-428. 
Przenosząc powyższe spostrzeżenia na grunt u.p.c.c., należy wskazać, że podstawa opodatkowania w przypadku przekształcenia została klarownie określona - jest to wartość wkładów do spółki osobowej powstałej w wyniku przekształcenia. Wynik wykładni językowej jest więc jednoznaczny. Jednocześnie brak argumentów za stwierdzeniem, że taki sposób interpretacji przepisu ustawy podatkowej miałby prowadzić do naruszenia istotnych dla systemu prawa wartości. Wniosek w postaci opodatkowania jedynie wartości wkładów do spółki przekształconej nie jest także absurdalny lub nieracjonalny. Wręcz przeciwnie - jest on spójny z systematyką u.p.c.c., gdzie w przypadku umowy spółki osobowej (oraz jej zmiany) podstawą opodatkowania jest wartość wkładów. To prowadzi również do wniosku, że nie można w tym przypadku mówić o wystąpieniu luki w prawie. Tym samym należy stwierdzić, że brak jest przesłanek, które uzasadniałyby odstąpienie od rezultatów wykładni językowej. Końcowo należy zauważyć, że odejście od rezultatów wykładni językowej nie mogłoby mieć miejsca także z tego względu, że prowadziłoby do zwiększenia ciężaru podatkowego i skutkowałoby pogorszeniem sytuacji podatnika.

\section{Identyfikacja argumentów natury celowościowej i systemowej}

Pomijając fakt, że w analizowanym przypadku nie jest możliwie odstąpienie od rezultatów wykładni językowej, warto jednak odnieść się do poglądów judykatury, w świetle których za opodatkowaniem przekształcenia w przypadku, gdy nie ma miejsca wniesienie (podwyższenie) wkładów przemawiają racje celowościowe i systemowe. W ocenie sądów za powyższym zapatrywaniem przemawia m.in. to, że doszłoby do: „(...) zasilenia w formie wkładów spółki osobowej, które nie podlegałyby opodatkowaniu podatkiem od majątku. W każdym innym przypadku zwiększenie majątku spółki osobowej, czy to poprzez wniesienie lub podwyższenie wkładów do spółki osobowej, dokonanie dopłat, udzielenie pożyczek, jak i oddanie spółce rzeczy lub praw majątkowych do nieodpłatnego używa- 
nia, implikuje opodatkowanie ich wartości (...)”33. Jednocześnie odmienne rozumowanie: „(...) stałoby w sprzeczności z celem systemowego i kompleksowego opodatkowania majątku spółki podatkiem od czynności cywilnoprawnych"34.

Odnosząc się do tak sformułowanych zapatrywań prawnych, w pierwszej kolejności należy wskazać, że w razie braku wniesienia (podwyższenia) wkładów przez wspólników w ramach przekształcenia nie dochodzi do zwiększenia majątku spółki. Spółka przekształcona jest bowiem kontynuatorem działalności spółki przekształcanej i zgodnie art. 553 § 1 Kodeksu spółek handlowych majątek spółki przekształcanej przysługuje jej z mocy prawa. Tym samym nie dochodzi wówczas do zwiększenia jej majątku. Już z tego powodu nie można zgodzić się z argumentacją prezentowaną w orzecznictwie.

Po drugie, wymaga podkreślenia, że opodatkowaniu PCC nie podlega każde zwiększenie majątku spółki, ale zwiększenie majątku związane z zaistnieniem wymienionych w ustawie enumeratywnie czynności. Dotyczy to m.in. wniesienia (podwyższenia) wkładów, udzielenia pożyczki oraz oddania spółce przez wspólnika rzeczy i praw majątkowych do nieodpłatnego używania. Tym samym trudno podzielić zapatrywanie, że „W każdym innym przypadku zwiększenie majątku spółki osobowej (...)” wiąże się z opodatkowaniem PCC. Dodatkowo, jak wskazano powyżej, opodatkowanie majątku spółki PCC ma charakter selektywny, stąd trudno mówić o założeniu „kompleksowego opodatkowania majątku spółki osobowej”. Należy także zauważyć, że opodatkowanie wartości wkładów wnoszonych do spółki przekształcanej jest spójne z systematyką u.p.c.c., gdzie w przypadku umowy spółki (lub jej zmiany) podstawą opodatkowania jest właśnie wartość wkładów wnoszonych przez wspólników. Tym samym należy stwierdzić, że racje systemowe nie przemawiają za opodatkowaniem przekształcenia, gdy w jego ramach wspólnicy nie wno-

33 Wyroki: NSA z 4 lutego 2020 r., II FSK 498/18, WSA w Poznaniu z 31 października 2017 r., I SA/Po 486/17 oraz WSA w Krakowie z 19 stycznia 2018 r., I SA/Kr 1270/17.

34 Wyroki: NSA z 4 lutego 2020 r., II FSK 498/18, WSA w Poznaniu z 31 października 2017 r., I SA/Po 486/17, WSA w Krakowie z 19 stycznia 2018 r., I SA/Kr 1270/17 oraz WSA w Warszawie z 24 lipca 2014 r. III SA/Wa 161/14. 
szą (nie podwyższają) wkładów. Wręcz przeciwnie - systematyka u.p.c.c. wspiera tezę, że opodatkowanie przekształcenia PCC powinno mieć miejsce jedynie w przypadku wniesienia (podwyższenia) wkładów.

Po trzecie, trudno również dostrzec jakiekolwiek racje celowościowe przemawiające za dominującym w orzecznictwie poglądem. Przekształcenie wiąże się jedynie ze zmianą formy prawnej podmiotu, natomiast (pomijając przypadek wniesienia lub podwyższenia wkładów) nie skutkuje ono zwiększeniem substancji majątkowej spółki przekształconej. Trafne w tym zakresie są spostrzeżenia WSA w Bydgoszczy, który wskazał m.in., że: „Nie ma żadnych racji ekonomicznych ani społecznych przemawiających za tym, aby pobierać podatek w sytuacji, gdy zmienia się tylko forma prawna prowadzonej działalności, lecz nie dochodzi do zwiększenia potencjału ekonomicznego spółki i nie występuje transfer rzeczy ani praw majątkowych. Trudno sobie wyobrazić, aby zamiarem prawodawcy było opodatkowanie takiej czynności, która polega tylko na zmianie formy prawnej spółki”35. Majątek spółki przekształconej nie ulega bowiem zwiększeniu - jest taki sam jak majątek spółki przekształcanej. W związku z tym należy stwierdzić, że nie istnieją względy celowościowe, które przemawiałyby za opodatkowaniem przekształcenia, gdy nie dochodzi do wniesienia (podwyższenia) wkładów.

\section{Zasada wyłączności ustawowej w zakresie opodatkowania i granice aktywizmu sędziowskiego}

Odnosząc się do poglądów judykatury, nie można także pominąć bardziej ogólnej, ale fundamentalnej dla prawa podatkowego kwestii. Obecnie nie budzi bowiem wątpliwości, że obowiązki podatkowe muszą mieć umocowanie ustawowe. Powyższe znajduje swoje odzwierciedlenie przede wszystkim w art. 217 Konstytucji Rzeczypospolitej Polskiej ${ }^{36}$, z którego

\footnotetext{
Wyrok WSA w Bydgoszczy z 14 lipca 2020 r., I SA/Bd 250/20.

Konstytucja Rzeczypospolitej Polskiej z 2 kwietnia 1997 r. (Dz.U. z 1997 r. Nr 483, poz. 78), dalej: Konstytucja.
} 
wynika, że nakładanie podatków, innych danin publicznych, określanie podmiotów, przedmiotów opodatkowania i stawek podatkowych, a także zasad przyznawania ulg i umorzeń oraz kategorii podmiotów zwolnionych od podatków następuje w drodze ustawy. W literaturze artykułuje się, że konsekwencją powyższego unormowania jest m.in. zasada wyłączności ustawowej w zakresie regulacji obowiązków podatkowych ${ }^{37}$.

Przenosząc powyższe spostrzeżenia na grunt u.p.c.c., należy zauważyć, że aby przekształcenie spółki osobowej w inną spółkę osobową podlegało opodatkowaniu, musi mieć miejsce wniesienie (podwyższenie) wkładów oraz majątek spółki musi ulec zwiększeniu. Niespełnienie którejkolwiek ze wskazanych wyżej przesłanek skutkuje brakiem możliwości opodatkowania przekształcenia PCC. Tymczasem w orzecznictwie widoczna jest tendencja do interpretacji u.p.c.c. w sposób, który nie znajduje odzwierciedlenia w brzmieniu przepisów ustawy podatkowej. Jak już zauważono, z art. 6 ust. 1 pkt 8 lit. f) u.p.c.c. wynika, że podstawą opodatkowania w przypadku przekształcenia jest wartość wkładów do spółki, nie zaś wartość majątku spółki przekształcanej. W orzecznictwie pojęcie wkładów jest natomiast utożsamiane z majątkiem spółki przekształcanej, co powoduje określenie podstawy opodatkowania w innej wysokości, niż wynika to z ustawy podatkowej.

W tym kontekście należy zwrócić uwagę na dostrzegane w doktrynie zjawisko tzw. aktywizmu sędziowskiego polegającego na odejściu od językowego brzmienia przepisu ustawy i dokonywaniu „twórczej” wykładni prawa, która ma uwzględniać istotne dla danej zbiorowości cele społeczno-gospodarcze, czy też uznawane przez nią wartości moralne ${ }^{38}$. Należy jednak podkreślić, że aktywizm sędziowski nie może prowadzić do zwiększania dolegliwości względem obywateli, w tym nie może skutkować ograniczeniem konstytucyjnie gwarantowanych praw i wolności.

37 B. Brzeziński, Zasady ogólne prawa podatkowego, „Toruński Rocznik Podatkowy” 2015, nr 1, s. 9; B. Brzeziński, Wstęp do nauki prawa podatkowego, Toruń 2003, s. 136-137; R. Mastalski, Prawo podatkowe, Warszawa 2014, s. 57 i 61.

38 T. Chauvin, T. Stawecki, P. Winczorek, Wstęp do prawoznawstwa, Warszawa 2011, s. 245-246. W przedmiocie zjawiska aktywizmu sędziowskiego zob. też A. Gomułowicz, Sędziowski aktywizm, „Zeszyty Naukowe Sądownictwa Administracyjnego” 2019, nr 6, s. 7-19. 
Tymczasem rezultatem dominującej obecnie linii interpretacyjnej jest nakładanie na obywateli (jednostki) obowiązku zapłaty podatku w przypadkach niewymienionych w ustawie. Tego typu wykładnia u.p.c.c. prowadzi więc do ograniczenia prawa własności (środki pieniężne), a więc dobra chronionego konstytucyjnie (art. 21 ust. 1 Konstytucji).

\section{Podsumowanie}

Na podstawie przeprowadzonej analizy można sformułować kilka wniosków. Po pierwsze, wartość wkładów do spółki przekształconej należy utożsamiać z wkładami wnoszonymi (podwyższanymi) przez wspólników. Wkładem do spółki przekształcanej nie jest natomiast majątek spółki przekształcanej, który - zgodnie z zasadą kontynuacji - stanie się majątkiem spółki przekształconej. Po drugie, zakładając, że w ramach przekształcenia nie ma miejsca wniesienie (podwyższenie) wkładów, majątek spółki przekształconej będzie zasadniczo taki sam, jak majątek spółki przekształcanej. To oznacza, że przekształcenie nie będzie skutkować zwiększeniem majątku spółki i w konsekwencji nie będzie podlegać opodatkowaniu PCC. Za powyższym wnioskiem przemawiają rezultaty wykładni językowej, jak również racje natury systemowej oraz celowościowej. Po trzecie, przyjęty w orzecznictwie sposób interpretacji u.p.c.c. powoduje naruszenie konstytucyjnej zasady wyłączności ustawowej w zakresie określania powinności podatkowych, ponieważ jednostki są zobowiązane do zapłaty PCC w sytuacjach, które zgodnie z brzmieniem ustawy podatkowej nie podlegają opodatkowaniu. Mając powyższe na względzie, należy stwierdzić, że dominująca linia orzecznicza nie jest trafna i w związku z tym wymaga zmiany. 


\section{Bibliografia:}

Borowy B., Komentarz do art. 28 Kodeksu spółek handlowych [w:] Z. Jara (red.), Kodeks spółek handlowych. Komentarz, Warszawa 2020, Legalis/el.

Brzeziński B., Wstęp do nauki prawa podatkowego, TNOiK, Toruń 2003.

Brzeziński B., Wykładnia prawa podatkowego [w:] Brzeziński B. (red.), Prawo podatkowe. Teoria. Instytucje. Funkcjonowanie, TNOiK, Toruń 2009.

Brzeziński B., Zasady ogólne prawa podatkowego, „Toruński Rocznik Podatkowy” 2015, nr 1, s. 5-18.

Chauvin T., Stawecki T., Winczorek P., Wstęp do prawoznawstwa, C.H. Beck, Warszawa 2011.

Drajewicz D., Zabezpieczenie majqtkowe w znowelizowanym Kodeksie postępowania karnego, „Palestra” 2017, nr 1-2, s. 79-94.

Filipczyk H., Komentarz do art. 6 u.p.c.c. [w:] H. Filipczyk, Podatek od czynności cywilnoprawnych. Komentarz, Warszawa 2015, LEX/el.

Gomułowicz A., Sędziowski aktywizm, „Zeszyty Naukowe Sądownictwa Administracyjnego” 2019, nr 6, s. 7-19.

Jagielski J., Obywatelstwo polskie. Komentarz do ustawy, Warszawa 2016, LEX/el., komentarz do art. 31.

Kalinowski M., Podmiotowość podatkowoprawna [w:] B. Brzeziński (red.), Prawo podatkowe. Teoria. Instytucje. Funkcjonowanie, TNOiK, Toruń 2009.

Karwat P., Przekształcenie spółki jawnej, komandytowej, partnerskiej i cywilnej w innq tego samego typu osobowq spółkę handlowq [w:] H. Litwińczuk (red.), Opodatkowanie spółek, Warszawa 2016, LEX/el.

Kidyba A., Kopaczyńska-Pieczniak K., Komentarz do art. 863 Kodeksu cywilnego [w:] A. Kidyba (red.), Kodeks cywilny. Komentarz. Tom III. Zobowiq̨zania - część szczególna, Warszawa 2014, LEX/el.

Konieczniak P., Uwagi o pojmowaniu typów zmodyfikowanych [w:] J. Brzezińska, J. Giezek (red.), Zmodyfikowane typy przestępstw w teorii i praktyce sqdowej, Warszawa 2017, LEX/el.

Kułak K., Wycofanie składnika majq̨tku spółki jawnej z działalności gospodarczej i nieodpłatne przekazanie go na użytek osobisty wspólników w świetle regulacji kodeksu spółek handlowych [w:] M. Dumkiewicz, K. KopaczyńskaPieczniak, J. Szczotka (red.), Sto lat polskiego prawa handlowego. Księga jubileuszowa dedykowana Profesorowi Andrzejowi Kidybie. Tom I, Warszawa 2020, LEX/el.

Mastalski R., Prawo podatkowe, C.H. Beck, Warszawa 2014. 
Michalski M., Komentarz do art. 200 Kodeksu spółek handlowych [w:] A. Kidyba (red.), Kodeks spółek handlowych. Tom II. Komentarz do art. 151-300, Warszawa 2018, LEX/el.

Morawski L., Wstęp do prawoznawstwa, TNOiK, Toruń 2009.

Morawski L., Zasady wykładni prawa, TNOiK, Toruń 2010, s. 120.

Radwański Z., Prawo cywilne - część ogólna, C.H. Beck, Warszawa 2005.

Rodzynkiewicz M., Komentarz do art. 553 Kodeksu spółek handlowych [w:] M. Rodzynkiewicz, Kodeks spółek handlowych. Komentarz, Warszawa 2018, LEX/el.

Tofel M., Komentarz do art. 553 Kodeksu spółek handlowych [w:] J. Bieniak, M. Bieniak, G. Nita-Jagielski, K. Oplustil, R. Pabis, A. Rachwał, M. Spyra, G. Suliński, M. Tofel, M. Wawer, R. Zawłocki, Kodeks spółek handlowych. Komentarz, Warszawa 2019, Legalis/el.

Zieliński M., Wyznaczniki reguł stosowania prawa, „Ruch Prawniczy, Ekonomiczny i Socjologiczny” 1998, nr 3 i 4, s. 1-20.

Żądło A., Przekształcenie spółki osobowej w innq spółkę osobowq [w:] A. Mariański (red.) Opodatkowanie spółek osobowych i ich wspólników, Warszawa 2018, LEX/el. 